\title{
BRAINSTEM EVOKED RESPONSE AUDIOMETRY IN HIGH RISK INFANTS
}

\author{
Brajesh Sharma ${ }^{1}$, Ruchi Shrivastava ${ }^{2}$, Asha Shrivastava ${ }^{3}$, Sanjeev Kumar Shrivastava ${ }^{4}$, Rashmi Dave $^{5}$, Jitendra Mahour 6
}

${ }_{1}^{1}$ rd Year Junior Resident, Department of Physiology, Gandhi Medical College, Bhopal.

$22^{\text {nd }}$ Year Junior Resident, Department of Physiology, Gandhi Medical College, Bhopal.

3 Professor and HOD, Department of Physiology, Mahavir Institute of Medical Sciences \& Research Centre, Bhopal.

${ }^{4}$ Assistant Professor, Department of Physiology, Gandhi Medical College, Bhopal.

${ }^{5}$ Assistant Professor, Department of Physiology, Gandhi Medical College, Bhopal.

${ }^{6}$ Assistant Professor, Department of Physiology, Gandhi Medical College, Bhopal.

\begin{abstract}
Brainstem Evoked Response Audiometry (BERA), being the most sensitive and specific test of hearing assessment in new-borns is beneficial for early detection of hearing impairment in high risk infants.

\section{BACKGROUND AND OBJECTIVE}

BERA was recorded in all high risk infants as defined by JCIH, 2007 criteria for identification of hearing deficits and to identify severity of hearing loss.

\section{MATERIAL AND METHODS}

45 high risk infants having one or more risk factors according to JCIH, 2007 criteria were selected on the basis of inclusion and exclusion criteria for the study and were compared with 30 age matched controls. BERA was performed using RMS EMG EP MK II machine and hearing threshold, absolute latencies of wave I, III and V were interpreted.

\section{RESULT AND DISCUSSION}

Mild hearing impairment was noticed in majority (55.5\%) of high risk infants. Wave I, V and I-V interpeak latency of left ear and wave I latency of right ear was found to be significantly prolonged $(p<0.05)$ in cases as compared to controls. Hypoxic Ischaemic Encephalopathy and neonatal hyperbilirubinaemia carry much higher risk of hearing impairment as compared to other high risk factors. Hypoxia of brainstem and cochlea resulting in changes at cellular level is believed to be the possible cause predisposing to auditory deficits.
\end{abstract}

\section{CONCLUSION}

Screening by BERA at an early age is beneficial for early diagnosis of hearing impairment, so that possible interventions can be used as early as possible and prevent developmental delays in newborns.

\section{KEYWORDS}

BERA, High Risk Infants, Hearing Impairment.

HOW TO CITE THIS ARTICLE: Sharma B, Shrivastava R, Shrivastava A, et al. Brainstem evoked response audiometry in high risk infants. J. Evolution Med. Dent. Sci. 2016;5(39):2363-2366, DOI: 10.14260/jemds/2016/549

\section{INTRODUCTION}

Hearing plays a basic and important role in language, speech and intellectual development. ${ }^{1} \mathrm{~A}$ hearing impaired child develops psychological, social, educational and even cognitive problems. ${ }^{2}$ as auditory deficit has major consequences on language and communication skills development. ${ }^{3}$ This can happen even if the child is having partial hearing impairment and is not totally deaf. $2,4,5$

Late detection causes irreversible stunting of the language development potential of the child. Unfortunately, the average time between birth and the detection of congenital Sensorineural (SN) hearing loss is 2.5 years. Such delays may result in lower educational and employment levels in adulthood.

Financial or Other, Competing Interest: None.

Submission 30-03-2016, Peer Review 21-04-2016,

Acceptance 30-04-2016, Published 13-05-2016.

Corresponding Author:

Dr. Sanjeev Kumar Shrivastava,

F-95/26 Tulsi Nagar

Near Jai Prakash Hospital,

Bhopal-462003.

E-mail: sanjeevshrivastava8@gmail.com

DOI: $10.14260 /$ jemds $/ 2016 / 549$
Early detection and intervention would help to maximize linguistic competence and literacy development for children who are deaf or hard of hearing. The American Joint Committee on Infant Hearing recommended that audiological rehabilitation should begin within the first 6 months of life. 6

Measurement of the Auditory Brainstem Response (ABR) is considered the most sensitive method of assessing the auditory activity of neonates. ${ }^{1}$

Joint Committee on Infant Hearing (JCIH). ${ }^{7}$ listed specific risk factors to identify infants at risk for hearing impairment for careful follow-up and assessment. The risk factors according to JCIH are family history, prematurity, birth asphyxia, hyperbilirubinaemia at serum levels requiring any intervention, in-utero infections, craniofacial anomalies, birth weight $<1500 \mathrm{~g}$, ototoxic medications and postnatal asphyxia.

The study of brainstem evoked response audiometry provides an opportunity to evaluate the functional integrity of auditory pathway from inner ear to upper brainstem.

Several studies have shown that early and adequate intervention of infants with congenital hearing loss minimizes future problems with speech and language development.8,9 With this background in mind, the research study was planned to investigate the presence of hearing impairment in infants at 
high risk of developing auditory deficit and future consequences as per the inclusion criteria and also to identify the type of hearing loss.

\section{AIM}

Identification of hearing impairment by brainstem evoked response audiometry in high risk infants developing auditory deficits and its future consequences.

\section{Primary Objectives}

To record brainstem auditory evoked response in high risk infants and compare with age specific normal response for identification of hearing impairment if any.

\section{Grading of Severity of Hearing Impairment.10,11}

\begin{tabular}{|c|c|}
\hline $\begin{array}{c}\text { Severity of Hearing } \\
\text { Impairment }\end{array}$ & $\begin{array}{c}\text { Hearing Threshold of } \\
\text { Better Ear }\end{array}$ \\
\hline Mild Hearing Impairment & $26-40 \mathrm{~dB}$ \\
\hline $\begin{array}{c}\text { Moderate Hearing } \\
\text { Impairment }\end{array}$ & $41-60 \mathrm{~dB}$ \\
\hline Severe Hearing Impairment & $61-80 \mathrm{~dB}$ \\
\hline $\begin{array}{c}\text { Profound Hearing } \\
\text { Impairment }\end{array}$ & $>80 \mathrm{~dB}$ \\
\hline
\end{tabular}

\section{MATERIALS AND METHODS}

The present study was conducted in the Neurophysiology Laboratory of Department of Physiology, Gandhi Medical College, Bhopal, in collaboration with the Department of Paediatrics, Gandhi Medical College and Hamidia Hospital, Bhopal. The study was approved by the Institutional Ethical Committee (Approval no. 10292-93/MC/7/2015). All the patients were referred to the Department of ENT of the institution for thorough ENT check-up and to exclude any ear pathology.

45 high risk infants hospitalized in Department of Paediatrics, Kamla Nehru Hospital, associated with Gandhi Medical College, Bhopal, having one or more risk factors according to criteria designated by JCIH 2007 and 30 age matched controls from paediatric OPD were selected for the study.

Risk indicators associated with permanent congenital, delayed-onset or progressive hearing loss in childhood as defined by the $2007 \mathrm{JCIH}$ position statement are listed as follows. ${ }^{7}$

\begin{tabular}{|c|l|}
\hline 1. & $\begin{array}{l}\text { Caregiver concern regarding hearing, speech, } \\
\text { language or developmental delay. }\end{array}$ \\
\hline 2. & Family history of permanent childhood hearing loss. \\
\hline 3. & $\begin{array}{l}\text { Neonatal intensive care of more than 5 days or any of } \\
\text { the following regardless of length of stay: ECMO, } \\
\text { assisted ventilation, exposure to ototoxic } \\
\text { medications (Gentamycin and tobramycin) or loop } \\
\text { diuretics (furosemide/Lasix) and } \\
\text { hyperbilirubinaemia that requires exchange } \\
\text { transfusion. }\end{array}$ \\
\hline 4. & $\begin{array}{l}\text { In-utero infections such as CMV, herpes, rubella, } \\
\text { syphilis and toxoplasmosis. }\end{array}$ \\
\hline 5. & $\begin{array}{l}\text { Craniofacial anomalies including those that involve } \\
\text { the pinna, ear canal, ear tags, ear pits and temporal } \\
\text { bone anomalies. }\end{array}$ \\
\hline
\end{tabular}

\begin{tabular}{|c|l|}
\hline 6. & $\begin{array}{l}\text { Physical findings such as white forelock that are } \\
\text { associated with a syndrome known to include a } \\
\text { sensorineural or permanent conductive hearing loss. }\end{array}$ \\
\hline 7. & $\begin{array}{l}\text { Syndromes associated with hearing loss or } \\
\text { progressive or late-onset hearing loss such as } \\
\text { neurofibromatosis, osteopetrosis and Usher } \\
\text { syndrome; other frequently identified syndromes } \\
\text { include Waardenburg, Alport, Pendred and Jervell } \\
\text { and Lange-Nielson. }\end{array}$ \\
\hline 8. & $\begin{array}{l}\text { Neurodegenerative disorders such as Hunter } \\
\text { syndrome or sensory motor neuropathies, such as } \\
\text { Friedreich ataxia and Charcot-Marie-Tooth } \\
\text { syndrome. }\end{array}$ \\
\hline 9. & $\begin{array}{l}\text { Culture-positive postnatal infections associated with } \\
\text { sensorineural hearing loss including confirmed } \\
\text { bacterial and viral (Especially herpes viruses and } \\
\text { varicella) meningitis. }\end{array}$ \\
\hline 10. & $\begin{array}{l}\text { Head trauma, especially basal skull/temporal bone } \\
\text { fracture that requires hospitalization. }\end{array}$ \\
\hline 11. & Chemotherapy. \\
\hline
\end{tabular}

\section{Inclusion Criteria}

Babies aged less than 1 year with one or more risk factor that may cause hearing impairment as defined by JCIH. ${ }^{7}$ and whose parents gave consent to participate.

\section{Exclusion Criteria}

Babies critically ill, more than 1 year of age, having atresia or stenosis of auditory tube or infected ears and whose parents not willing for participation of their baby in the study.

45 high risk babies and 30 age matched controls satisfying inclusion and exclusion criteria were subjected to BERA using RMS EMG EP MK-II machine. Written consent was taken by the parents and the whole procedure was explained to them. Drug used for sedation was syrup Triclofos (Pedicloryl) $20 \mathrm{mg} / \mathrm{kg}$ body wt. Test was carried out in precooled, quiet, dimly lit room. Electrical activities were recorded using silver electrodes $(\mathrm{Ag} / \mathrm{AgCl})$.

The mono-aural montage, i.e. $\mathrm{Cz}-\mathrm{M} 1 / \mathrm{M} 2$ was used; $\mathrm{Cz}$ (Forehead at the hairline) =Reference electrode $\mathrm{Fpz} / \mathrm{Fz}$ (Nasion)=Ground Electrode; M1/M2 (Mastoid)=Active or recording electrode. Conductive electrolyte paste was used to fix the electrodes. Resistance was kept below 5 Kohms. The stimulus in the form of click was transmitted to the ears via acoustically shielded THD 32 head phone.

Mono-aural auditory stimulus consisting of rarefaction clicks of 100 microseconds with intensities starting from $30 \mathrm{~dB}$ to $90 \mathrm{~dB}$ was delivered at a rate of $11.1 / \mathrm{sec}$. Contralateral ear was masked with intensity $30 \mathrm{~dB}$ less than the stimulus intensity. The filter settings $100 \mathrm{~Hz}-3000 \mathrm{~Hz}$ were used; 2000 responses were averaged and the process was repeated at least once to ensure reproducibility of the response. Electrophysiological variables were recorded in both ears for following interpretation:

- Hearing threshold.

- Wave I, III, V absolute latencies.

- Wave I-V Inter-Peak Latencies (IPL).

Peaks of waves I, III and V were marked manually after proper identification. The absolute latencies of the waves I, III 
and V, the interpeak latencies; i.e. the latencies of inter-wave intervals were obtained automatically by means of a computer program.

\section{OBSERVATIONS AND RESULT}

\begin{tabular}{|c|c|c|c|c|c|c|}
\hline Parameters & \multicolumn{2}{|c|}{$\begin{array}{c}\text { Cases } \\
(\mathbf{n = 4 5})\end{array}$} & \multicolumn{2}{c|}{$\begin{array}{c}\text { Controls } \\
(\mathbf{n = 3 0})\end{array}$} & \multicolumn{2}{c|}{$\begin{array}{c}\text { Cases vs } \\
\text { Controls }\end{array}$} \\
\hline $\begin{array}{c}\text { Absolute } \\
\text { Latency }\end{array}$ & Mean & SD & Mean & SD & t & $\begin{array}{c}\text { P - } \\
\text { Value }\end{array}$ \\
\hline I & 1.84 & 0.29 & 1.51 & 0.13 & 5.84 & $<0.05^{*}$ \\
\hline III & 4.02 & 0.41 & 4.10 & 0.16 & 1.01 & $\mathrm{NS}$ \\
\hline V & 6.03 & 0.52 & 6.41 & 0.24 & 3.73 & $<0.05^{*}$ \\
\hline I-V IPL & 4.19 & 0.57 & 4.90 & 0.22 & 6.49 & $<0.05^{*}$ \\
\hline \multicolumn{6}{c}{ Table 1: Comparison of Left Ear Bera } \\
Recordings of Cases \& Controls \\
\hline
\end{tabular}

*Statistically Significant, NS=Not significant

Comparison of BERA parameters of cases with controls in left ear revealed significant difference in the absolute peak latencies of wave I and wave V and wave I-V IPL. No significant difference was found in wave III absolute peak latency of left ear between cases and controls.

\begin{tabular}{|c|c|c|c|c|c|c|}
\hline Parameters & \multicolumn{2}{|c|}{$\begin{array}{c}\text { Cases } \\
(\mathbf{n}=45)\end{array}$} & \multicolumn{2}{c|}{$\begin{array}{c}\text { Controls } \\
(\mathbf{n}=30)\end{array}$} & \multicolumn{2}{c|}{$\begin{array}{c}\text { Cases vs } \\
\text { Controls }\end{array}$} \\
\hline $\begin{array}{c}\text { Absolute } \\
\text { Peak } \\
\text { Latency } \\
\text { (ms) }\end{array}$ & Mean & SD & Mean & SD & $\mathbf{t}$ & $\begin{array}{c}\mathbf{P}- \\
\text { value }\end{array}$ \\
\hline I & 1.80 & 0.31 & 1.6 & 0.15 & 3.28 & $\begin{array}{c}<0.0 \\
5^{*}\end{array}$ \\
\hline III & 3.97 & 0.43 & 3.82 & 0.17 & 1.81 & 0.07 \\
\hline V & 5.87 & 0.47 & 5.81 & 0.21 & 0.65 & 0.51 \\
\hline I-V IPL & 4.06 & 0.54 & 4.2 & 0.20 & 1.35 & 0.17 \\
\hline \multicolumn{3}{|c}{ Table 2: Comparison of Right Ear BERA } \\
Parameters of Cases \& Controls \\
\hline
\end{tabular}

*Statistically Significant, NS=Not significant.

Statistical analysis of BERA parameters of cases and controls in right ear revealed significant difference in the absolute peak latency of wave I only. Other parameters were statistically insignificant.

\begin{tabular}{|c|c|}
\hline $\begin{array}{c}\text { Grading of Hearing } \\
\text { Impairment }\end{array}$ & $\begin{array}{c}\text { Number of Babies } \\
(\mathbf{N}=45)\end{array}$ \\
\hline Normal Hearing Sensitivity & $07(15.5 \%)$ \\
\hline Mild Hearing Impairment & $25(55.5 \%)$ \\
\hline Moderate Hearing Impairment & $08(17.7 \%)$ \\
\hline Severe Hearing Impairment & $03(6.6 \%)$ \\
\hline Profound Hearing Impairment & $02(4.4 \%)$ \\
\hline \multicolumn{2}{|c|}{ Table 3: Distribution of Severity of Hearing } \\
Impairment in Cases (n=45)
\end{tabular}

An attempt was made to grade the hearing impairment in the study group as per the WHO guidelines. It was observed that majority of the cases (55.5\%) were having mild grade hearing impairment, eight cases were having moderate grade hearing impairment, whereas three and two cases were identified as having severe grade and profound grade hearing impairment respectively.

\begin{tabular}{|c|c|c|c|c|c|}
\hline GRADE & $\begin{array}{c}\text { NNH } \\
(n=12)\end{array}$ & $\begin{array}{c}\text { GDD } \\
(\mathrm{n}=14)\end{array}$ & $\begin{array}{c}\text { HIE } \\
(n=5)\end{array}$ & $\begin{array}{c}\text { Ototoxic } \\
\text { Drug } \\
\text { Exposure } \\
>5 \text { days } \\
(n=7)\end{array}$ & $\begin{array}{l}\text { LBW } \\
(n=7)\end{array}$ \\
\hline $\begin{array}{c}\text { Normal } \\
\text { hearing } \\
\text { sensitivity }\end{array}$ & 01 & 03 & 02 & 01 & 00 \\
\hline $\begin{array}{c}\text { Mild } \\
\text { hearing } \\
\text { impairment }\end{array}$ & 06 & 09 & 03 & 02 & 05 \\
\hline $\begin{array}{c}\text { Moderate } \\
\text { hearing } \\
\text { impairment }\end{array}$ & 03 & 02 & 00 & 02 & 01 \\
\hline $\begin{array}{c}\text { Severe } \\
\text { hearing } \\
\text { impairment }\end{array}$ & 02 & 00 & 00 & 01 & 00 \\
\hline $\begin{array}{c}\text { Profound } \\
\text { hearing } \\
\text { impairment }\end{array}$ & 00 & 00 & 00 & 01 & 01 \\
\hline
\end{tabular}

On analysis of the distribution of severity of hearing impairment in cases with different risk factors, it was observed that in infants suffering from Neonatal Hyperbilirubinaemia (NNH) 50\% cases had mild-grade hearing impairment. Out of 14 cases with Global Developmental Delay (GDD), majority (64\%) showed mild-grade hearing impairment. Among the 05 cases with Hypoxic Ischemic Encephalopathy (HIE), only mild grade hearing impairment was recorded in 3 patients; 07 infants with ototoxic drug exposure 02 cases each of mild and moderate grade and 01 case each with severe and profound grade hearing impairment was recorded. Mild, moderate and profound grade hearing impairment was seen in 5, 1 and 1 case out of 7 Low Birth Weight (LBW) babies.

\section{DISCUSSION}

In our study, the incidence of hearing impairment in the high risk infants was $84.44 \%$ as comparable with the work of Eden and Ford. 12

There are several risk factors causing hearing impairment in new-born and young infants. Prematurity and low birth weight, asphyxia, hyperbilirubinaemia, use of aminoglycosides and other ototoxic drugs, bacterial meningitis and intrauterine infections, craniofacial anomalies and prolonged mechanical ventilation are among the high risk factors. ${ }^{13}$

BERA being rapid, easy and cheap test gives the electrophysiological response of hearing without any need for assessment of newborn behaviour. The result of this test is not affected by sedatives, which was used during the test. It is thus a useful and non-invasive tool for hearing assessment in newborn and infants. 14

The reported sensitivity of the BERA for hearing assessment was $100 \%$ and specificity around $86 \% .{ }^{15}$

We observed that infants exposed to high risk factors are prone for developing hearing abnormality. Among all the risk factors included in our study, hypoxic ischemic encephalopathy and neonatal hyperbilirubinaemia carry a much higher risk of hearing abnormality.

Bilirubin can deleteriously affect the auditory pathway anywhere along its course in the brainstem, although the cochlear nucleus is usually most involved. ${ }^{16,17}$ Animal studies suggest that acoustic trauma and aminoglycoside antibiotics may act synergistically to produce hearing loss in premature 
animals. ${ }^{18}$ Hypoxemia has been identified as a possible ototoxin according to Duara $\mathrm{S}$ et al ${ }^{19}$, Leech et al concluded that brainstem auditory nuclei are particularly susceptible to acute hypoxic insults in the neonates. ${ }^{20}$ So detection of hearing impairment during early stage and proper rehabilitative measures at the earliest reduces delay of developmental milestones.

Absolute latencies of wave III, wave V and IPL of I-V were increased among the high risk group compared to the control group.

Absolute latency of wave $\mathrm{V}$ is a consistent and stable parameter, which has received primary attention as a valuable factor in response evaluation. It is suggested that all the risk factors which bring the neonate under intensive care induce a certain amount of hypoxia of the cochlea and brainstem which leads to various cellular changes such as oedema, degeneration and necrosis. Hence, they predispose to hearing impairment which may be reversible following reversal of hypoxic changes. The I-V IPL is a reflection of neural conduction time between the auditory nerve and brainstem nuclei and reflects upon the efficiency of the auditory pathway. Prolonged I-V IPL is a feature of neurological and is an indication of delay in neural conduction within the brainstem. ${ }^{21}$ Thus hearing assessment by BERA at an early age in all high risk infants is very beneficial and can reduce morbidity associated with hearing impairment.

\section{CONCLUSION}

Hearing is not a visible disability. It commonly goes undetected until it affects the child's communication in the form of speech and language. This emphasizes the need for newborn screening. Screening program should be performed in the first year or preferably in the first 6 months of age to avoid speech and language developmental delays. The true value of screening may lie in identification of mild-to-moderate hearing losses that are amenable to treatment and if untreated may manifest as severe impairment. BERA gives an accurate picture of hearing sensitivity. Hence, in all high risk babies, BERA should be carried out as a routine procedure to detect hearing impairment. Regular follow-up should be done and rehabilitative measures should be started as early as possible.

\section{REFERENCES}

1. Bilgen H, Akman I, Ozek E, et al. Auditory brainstem response screening for hearing loss in high risk neonates. Turk J Med Sci 2000;30:479-82.

2. Biswas A. Clinical audio-vestibulometry for otologists and neurologists. Mumbai: Bhalani Medical Book House 2009; $4^{\text {th }}$ ed:100-32, 147-76.

3. Hearing deficits. Emerging research and applications to children. Synthesis. Collective expert report, inserm, national institute for health and medical research, Paris. 2006.

4. Homer JJ, Linney SL, Strachan DR. Neonatal hearing screening using the auditory brainstem response. Clin otolaryngol 2000;25(1):66-70.

5. Yoshinaga-Itano C, Sedey AL, Coulter DK, et al. Language of early and later-identified children with hearing loss. Paediatrics 1998;102(5):1161-71.
6. Glowacki J, Mulliken JB. Mast cells in haemangiomas and vascular malformations. American Academy of Paediatrics. Paediatrics 1982;70:496-7.

7. Risk assessment: JCIH risk indicators. Maternal and child health section. March 2014. Available from:

http://www.health.state.mn.us

/divs/cfh/topic/hearingscreening/content/downloads/R iskAssessmentJCIH.pdf

8. Nelson HD, Bougatsos C, Nygren P. Universal newborn hearing screening: systematic review to update the 2001 US preventive services task force recommendation. Paediatrics 2008;122(1):e266-76.

9. Sininger YS, Grimes A, Christensen E. Auditory development in early amplified children: factors influencing auditory-based communication outcomes in children with hearing loss. Ear and Hearing 2010;31(2):166-85.

10. Valkama M. Prediction of neurosensory disability in very low birth weight preterm infants (dissertation), University of Oulu, Finland, 2001.

11. American speech-language-hearing association. Short latency auditory evoked potentials: audiologic evaluation working group on evoked potential measurements. URL: 1987. www.asha.org/policy.

12. Eden D, Ford RP, Hunter MF, et al. Audiological screening of neonatal intensive care unit graduates at high risk of sensorineural hearing loss. NZ Med J 2000;113(1110):182-3.

13. Joint Committee on Infant Hearing. Position statement: principles and guidelines for early hearing detection and intervention programs. Paediatrics 2007;120(4):898-921.

14. Van SH. Automated auditory brainstem response testing for universal newborn hearing screening. Acta Paediatr 1999;88:76-9.

15. Shannon DA, Felix JK, Krumholz A, et al. Hearing screening of high-risk newborns with brainstem auditory evoked potentials: a follow-up study. Paediatr 1984;73(1):22-6.

16. Chisin R, Perlman M, Sohmer H. Cochlear and brainstem responses in hearing loss following neonatal hyperbilirubinaemia. Ann Otol Rhinol Laryngol 1979;88(3 Pt 1):352-7.

17. Perlman M, Fainmesser P, Sohmer H, et al. Auditory nerve -brainstem evoked responses in hyperbilirubinaemic neonates. Paediatr 1983;72(5):658.

18. Falk SA, Farmer JC. Incubator noise and possible deafness. Arch Otolaryngol 1973;97(5):385-7.

19. Duara S, Suter CM, Bessard KK, et al. Neonatal screening with auditory brainstem responses: results of follow-up audiometry and risk factor evaluation. J Paediatr 1986;108(2):276-81.

20. Leech RW, Alvird EC. Anoxic-ischemic encephalopathy in the human neonatal period. The significance of brainstem involvement. Arch Neurol 1977;34(2):109-13.

21. Lakshmi T, Zaheera Sultana S, Brid SV. Evoked response audiometry in high risk infants. International Journal of Recent Trends in Science and Technology 2014;12(1):0812. 